\title{
IMMUNE RELATED GENES EXPRESSION ANALYSIS IN KOI FISH AFTER VACCINATED WITH KOI HERPES VIRUS DNA VACCINES
}

\author{
Sri Nuryati*\#, Fauzan Wahib Alsani*), Hasan Nasrullah*), Odang Carman*), Yuni Puji Hastuti*), \\ Eni Kusrini**), and Alimuddin*) \\ *) Department of Aquaculture, Faculty of Fisheries and Marine Sciences, IPB University (Bogor Agricultural University) \\ Jl. Agatis IPB Dramaga Campus, Bogor, 16680, West Java, Indonesia \\ *) Research Institute for Ornamental Fish Culture, Ministry of Marine and Fisheries, Depok West-Java Indonesia
}

(Received 29 November 2019; Final revised 25 March 2020; Accepted 28 March 2020)

\begin{abstract}
Vaccination is a practical step in preventing diseases caused by koi herpes virus (KHV) in koi fish (Cyprinus carpio haematopterus). We have developed two DNA vaccines for KHV named as GP-25 and GP-11 from two local isolates coded as ORF25 and ORF81, respectively. Although both vaccines have been reported to increase survival rates, the evaluation of koi fish immune responses at the molecular level has not been done post-vaccinations. The aim of this research was to determine the effects of koi herpesvirus DNA vaccine on the immune-modulation of koi fish at mRNA level. This recent research used the best vaccine doses of both vaccines determined from our previous study: 7.5 and $12.5 \mu \mathrm{g}$ per $100 \mathrm{~g}$ fish of GP-11, and $12.5 \mu \mathrm{g}$ per $100 \mathrm{~g}$ fish of GP-25. The immune gene expression was analyzed using the RT-qPCR method from the fish liver at $0,1,7,14$, and 28 days post-vaccination (dpv). The results showed that, in the vaccinated fish, the immune genes viz. tumor necrosis factor $\alpha$ (TNF $\alpha$ ), interleukin-1 $\beta$ (IL1 $\beta$ ), interferon- $\gamma$ $(\mathrm{IFN} \gamma), \mathrm{Mx1}$, immunoglobulin Mu chain (IgM), and major histocompatibility complex (MHC) class I and class II were induced to significant extents. The higher dose vaccination using the GP-11 vaccine showed higher immune gene expression than that of the lower dose. Furthermore, the GP-25 vaccine had induced lower immune responses than the GP-11 vaccine when using the same dose of vaccination, but relatively the same when the half-dose of GP-11 vaccine was used. In conclusion, the GP-11 and GP-25 vaccine provided the immune-modulatory effects on the koi fish immune response after vaccination.
\end{abstract}

\section{KEYWORDS: DNA vaccine; gene expression; immune response; KHV; koi}

\section{INTRODUCTION}

Koi herpes virus (KHV), also known as Cyprinid Herpesvirus 3 (CyHV-3), is one of the pathogens causing high mortality and economic losses in common carp as well as ornamental cyprinid fish such as goldfish and koi carp. KHV is a group of double-stranded DNA viruses from the Alloherpesviridae family that encode156 functional Open Reading Frames (ORFs) (Aoki et al., 2007). When infecting carp and koi, KHV is referred to as koi herpes virus disease (KHVD). This viral infection can cause a massive death from $80 \%$ up to $100 \%$ showing clinical symptoms from redcolored spots and wounds to tissue damages in the gills. The infection usually occurs at low water tem-

\footnotetext{
\# Correspondence:Department of Aquaculture, Faculty of Fisheries and Marine Sciences, IPB University (Bogor Agricultural University). Jl. Agatis IPB Dramaga Campus, Bogor, 16680, West Java, Indonesia Tel.: + 62251 8622755; 8622941

E-mail: sri_nuryati@ apps.ipb.ac.id
}

peratures $\left(18^{\circ} \mathrm{C}-27^{\circ} \mathrm{C}\right)$, especially during the rainyseason (Eide et al., 2011; Mccoll et al., 2018). When a KHV outbreak has occurred, it is difficult to treat or localize the disease distribution. This means that the best option in KHV disease management is preventing a possible disease outbreak before it happens considering that KHV virus can be latent in fish (Aonullah et al., 2016; Eide et al., 2011; Nuryati et al., 2015).

Vaccination is a practical step in preventing KHV disease. One of the most currently promising vaccine preparations against fish diseases is a DNA vaccine. The vaccine consists of plasmid DNA that will produce the gene expression of the pathogenic proteins in the vaccinated fish (Collins et al., 2018). Moreover, a DNA vaccine does not cause infection, is relatively stable and could activate humoral and cellular defenses infish (Chairunnisa et al., 2016; Cui et al., 2015; Zhu et al., 2015). We have developed a DNA vaccine for KHVD from the ORF25 and ORF81 of local 
isolates, namely GP-25 and GP-11 vaccine, respectively (Nuryati et al., 2010). Several experiments using both DNA vaccines against KHV showed the alteration of fish protection against KHVD in koi. Vaccination of koi with the GP-25 vaccine at a dose of $12.5 \mu \mathrm{g}$ per $100 \mathrm{~g}$ by intramuscular injection was able to increase fish survival rates to $96.67 \%$ after the KHV challenge (Nuryati et al., 2010). Chairunnisa et al. (2016) also reported that vaccination of koi fish using the GP-11 vaccine with a dose of $7.5 \mu \mathrm{g}$ and $12.5 \mu \mathrm{g}$ per $100 \mathrm{~g}$ was able to increase the fish's survival rate to $93.3 \%$ after the challenge test with KHV.

Although both vaccines were able to increase survival rates, the evaluation of koi fish immune responses at the molecular level has not been done post-vaccination. Given the promising results from previous studies, this current study was aimed to investigate the potential use and effects of the GP25 and GP-11 DNA vaccines to increase the various immune response of fish at the mRNA level.

\section{MATERIALS AND METHODS}

\section{Fish and Vaccine Preparation}

Koi fish (mixed from Kohaku, Sanke, and Ki bekko strain) with an average body weight of $28.55 \pm 0.98$ $g$ were obtained from the National Center of Freshwater Aquaculture, Sukabumi, West-Java, Indonesia. Before the experiment, the fish were checked for the possibility of carrying KHV using the PCR method (OIE, 2019). The fish were acclimated for seven days in the aquarium sized $60 \mathrm{~cm} \times 40 \mathrm{~cm} \times 30 \mathrm{~cm}$, and the temperature was maintained between $27^{\circ} \mathrm{C}-28^{\circ} \mathrm{C}$. The fish were fed with commercial pellets ( $21 \%$ protein) three times a day. No observed clinical symptoms of KHV or pathogen infection during the acclimatization.

Bacteria Escherichia coli DH5 $\alpha$ containing GP-11 and GP-25 KHV vaccine were cultured in a1 L of $2 \times$ YT broth media and spun at 37 and 200 rpm for 18 hours. The bacterial pellet was harvested by centrifugation at $8,000 \mathrm{rpm}$ for $5 \mathrm{~min}$ at $4^{\circ} \mathrm{C}$. The plasmid DNA was purified using the GeneJET Plasmid Miniprep Kit (Thermofisher Scientific, USA) following the manual instruction. The concentration and purity of the plasmid DNA were measured using spectrophotometry method at 260 and $280 \mathrm{~nm}$ and verified by PCR method using the specific primer for the corresponding ORFs.

\section{Vaccination and Sample Collection}

In this study, we used the best vaccine doses of both vaccine types from our previous study, viz. 12.5 $\mu \mathrm{g}$ per $100 \mathrm{~g}$ fish for GP-25 vaccine, and 7.5 and 12.5 $\mu \mathrm{g}$ per $100 \mathrm{~g}$ fish for GP-11 vaccine as presented in Table 1. The vaccination was conducted by injecting
$0.1 \mathrm{~mL}$ DNA vaccine intramuscularly near the dorsal fin, $n=15$, with three replications for each treatment. The fish were reared in 12 aquariums $(60 \mathrm{~cm} \mathrm{x}$ $40 \mathrm{~cm} \times 30 \mathrm{~cm}$ ) for 28 days post-infection (15 fish/ aquarium). The fish were fed with commercial feed at satiation three times a day.

The samples for the gene expression were collected at $0,1,7,14$, and 28 days post-vaccination (dpv). The fish were euthanized using tricaine methanesulfonate (MS222) and then dissected. The fish's kidneys were collected and stored in the GENEzol reagent (Geneaind, Taiwan) at " $80^{\circ} \mathrm{C}$ before the gene expression analysis.

\section{Total RNA Isolation, cDNA Synthesis, and RT- qPCR Analysis}

Total RNA was isolated from the sampled kidneys (23.07 $\pm 2.3 \mathrm{mg}$ ) using the GENEzol reagent (Geneaid, Taiwan) following the manufacturer's instruction. RNA concentration and purity were measured using the spectophotometry method at 260 and $280 \mathrm{~nm}$. The cDNA synthesis was carried out from $100 \mathrm{ng} \mu \mathrm{L}^{-1}$ RNA using the Revertra ${ }^{\circledR}$ Ace qPCR RT Mastermix with gDNA removalkit (Toyobo, Japan) following the manual procedure. Real-time quantitative PCR (RT-qPCR) was used to determine the levels of immune-genes after vaccination. The primers were designed based on the references and available sequences in GenBank (ncbi.nlm.nih.gov/genbank) using the Primer3 web program (primer3.ut.ee/). The primers sequence was summarized in Table 2 . The qPCR reaction was performed in the Rotor-Gene 6000 (Corbett, USA) machine using $2 x$ SensiFAST SYBR ${ }^{2}$ NO-ROX (Bioline, UK) from the $50 \mathrm{ng} \mu \mathrm{L}^{-1} \times \mathrm{CNA}$ in the total volume of $20 \mu \mathrm{L}$. The reaction consisted of $10 \mu \mathrm{L}$ qPCR enzyme mix, $0.8 \mu \mathrm{L}$ of each qPCR primer $(10 \mathrm{mMol}), 4 \mu \mathrm{L}$ cDNA, and $14.4 \mu \mathrm{L}$ nucleases free water. The amplifying program was set at $95^{\circ} \mathrm{C}$ for two min, and 40 cycles of $95^{\circ} \mathrm{C}$ for $10 \mathrm{~s}, 60^{\circ} \mathrm{C}$ for $15 \mathrm{~s}$, and $72^{\circ} \mathrm{C}$ for 10 $\mathrm{s}$. The expression levels of all the genes were analyzed according to the $2^{-\Delta \Delta C T}$ method (Livak \& Schmittgen, 2001) after normalized with the $\beta$-actin gene and compared to the PBS control at $0 \mathrm{dpv}$ as the expression calibrator. The statistical analysis was conducted in the SPSS v.17 software (IBM, USA) with the one-way ANOVA test and Duncan post-test at $p=0.05$.

\section{RESULTS AND DISCUSSION}

The effect of vaccination on the expression of immune genes was examined using RT-qPCR analysis of the transcription of the genes encoding tumor necrosis factor $\alpha$ (TNF $\alpha$ ), interleukin-1 $\beta$ (IL1 $\beta$ ), interferon- $\gamma$ (IFN $\gamma$ ), $M x 1$, immunoglobulin $M u$ chain $(\mathrm{IgM})$, and major histocompatibility complex (MHC) class-I and class-II. The results showed that in the 
Table 1. Experimental design of koi fish vaccinated with GP-11 and GP-25 DNA vaccines

\begin{tabular}{ccc}
\hline Treatments & DNA vaccine and dose & Number of fish \\
\hline A & GP- $11 ; 7.5 \mu \mathrm{g} / 100 \mathrm{~g}$ & $15 \times 3$ \\
$\mathrm{~B}$ & $\mathrm{GP}-11 ; 12.5 \mu \mathrm{g} / 100 \mathrm{~g}$ & $15 \times 3$ \\
C & GP-25;12.5 $\mu \mathrm{g} / 100 \mathrm{~g}$ & $15 \times 3$ \\
Control & PBS control;0.1 mL & $15 \times 3$ \\
\hline
\end{tabular}

Table 2. Primers sequence used to determine the immune response by RT-qPCR analysis on koi fish after vaccinated with GP11 and GP 25 DNA vaccines

\begin{tabular}{|c|c|c|c|}
\hline Gene & $\begin{array}{l}\text { Sequence } \\
5^{\prime}-3^{\prime}\end{array}$ & $\begin{array}{l}\text { PCR product size } \\
\text { (bp) }\end{array}$ & $\begin{array}{l}\text { Reference/Genbank } \\
\text { accession no. }\end{array}$ \\
\hline $\lg M$ & $\begin{array}{l}\text { F: CACAAGGCGGGAAATGAAGA } \\
\text { R: GGAGGCACTATATCAACAGCA }\end{array}$ & 86 & Embregts et al . (2018) \\
\hline IFNY & $\begin{array}{l}\text { F: CGATCAAGGAAGATGACCCAGTC } \\
\text { R: GTTGCTTCTCTGTAGACACGCTTC }\end{array}$ & 73 & Embregts et al . (2018) \\
\hline TNFa & $\begin{array}{l}\text { F: GCTGTCTGCTTCACGCTCAA } \\
\text { R: CCTTGGAAGTGACATTTGCTTTT }\end{array}$ & 106 & JX181982.1 \\
\hline $\mathrm{MHCl}$ & $\begin{array}{l}\text { F: AGAAAGCTGTGCCGAAGACA } \\
\text { R: GGCGGCCAATATCAGTCTGA }\end{array}$ & 87 & HM372879.1 \\
\hline $\mathrm{MHC2}$ & $\begin{array}{l}\text { F: TACTACCAGATTCACTCGG } \\
\text { R: CGGGTTCCAGTCAAAGAT }\end{array}$ & 111 & Zhu et al. (2015) \\
\hline ILI $\beta$ & $\begin{array}{l}\text { F: ACGCTGAGAGACGGAAACAG } \\
\text { R: CGACTCGGTACAAGCAAGGT }\end{array}$ & 141 & MK942107.1 \\
\hline$M \times 1$ & $\begin{array}{l}\text { F: TGACATTGCAACCACAGAAGC } \\
\text { R: ATCCACCAGATCCGGCTTTG }\end{array}$ & 97 & KP115357.1 \\
\hline$\beta$-actin & $\begin{array}{l}\text { F:ACCGGAGTCCATCACAATACC } \\
\text { R: GAGCTGCGTGTTGCCCCTGAG }\end{array}$ & 192 & AY395870.2 \\
\hline
\end{tabular}

vaccinated fish, all these genes were induced to significant extents (Figure 1-3). Interferon-gamma (IFN $\gamma$ ) or type-II interferon is a cytokine that is critical for innate and adaptive immunity against viral and some bacterial infections. The importance of IFN- $\gamma$ in the immune system lies in its ability to inhibit viral replication directly and, most importantly, from its immunomodulatory effects (Bedekar et al., 2018; Zou $\&$ Secombes, 2016). In this study, IFN $\gamma$ of vaccinated fish were modulated higher than the control since 1 $d p v$ and maintained its high expression until $28 \mathrm{dpv}$ (Figure 1). GP-11 vaccines gave significantly higher up-regulation than GP-25 with the same dose. Furthermore, the interferon-stimulated gene (ISG), namely $M x$ protein genes, was also observed in this study (Kim et al., 2000; Leong et al., 1998). The Mx1 gene expression was modulated mainly after $7 \mathrm{dpv}$ in the vaccinated fish and higher in the GP-11 treatment (Figure 1). The modulation of Mxl gene showed that the GP-11 and GP-25 vaccines appear to stimulate the IFN-signalling pathway, one of the most important innate immune responses (Kim et al., 2000; Lazarte et al., 2017).

The modulation of the IFN-signalling pathway after GP- 11 and GP-25 vaccine is also supported by the result of the inflammatory cytokine expression. The modulation of the IFN-signalling pathway will promote the inflammatory cytokines to trigger other immune responses cascade in fish (Sobhkhez et al., 2018). IL1 $\beta$ and TNF $\alpha$ are the inflammatory cytokines that have the primary role in the regulation of the immune cells, that enables organisms to respond to microbial invasion, and is involved in a variety of cellular activities (Bird et al., 2002; Zou \& Secombes, 2016). In this study, the IL1 $\beta$ and TLR $\alpha$ expressions were altered rapidly and significantly higher in vaccinated fish, in line with the IFN $\gamma$ alteration (Figure 2). 

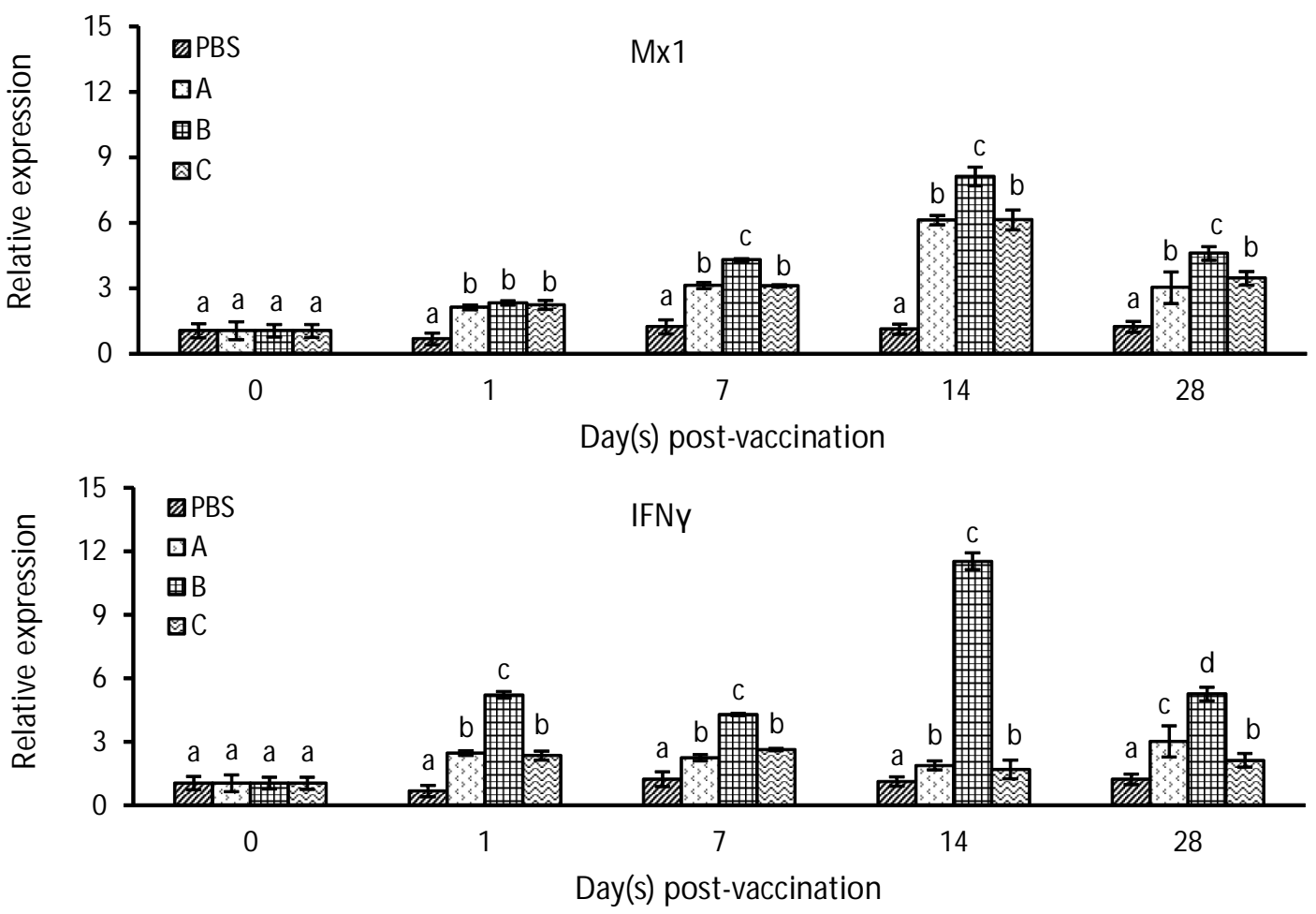

Figure 1. Quantitative relative mRNA expression of IFN $\gamma$ and $M \times 1$ of koi fish after vaccination with GP-11 and GP-25 DNA vaccine; (A) $7.5 \mu \mathrm{g} / 100 \mathrm{~g}$ fish GP-11, (B) $12.5 \mu \mathrm{g} /$ $100 \mathrm{~g}$ fish GP-11, (C) $12.5 \mu \mathrm{g} / 100 \mathrm{~g}$ GP-25, (K) PBS control. Data were shown as mean expression $\pm S D(n=3)$. Different letters indicate the significant difference of expression within the treatments at the same time points.
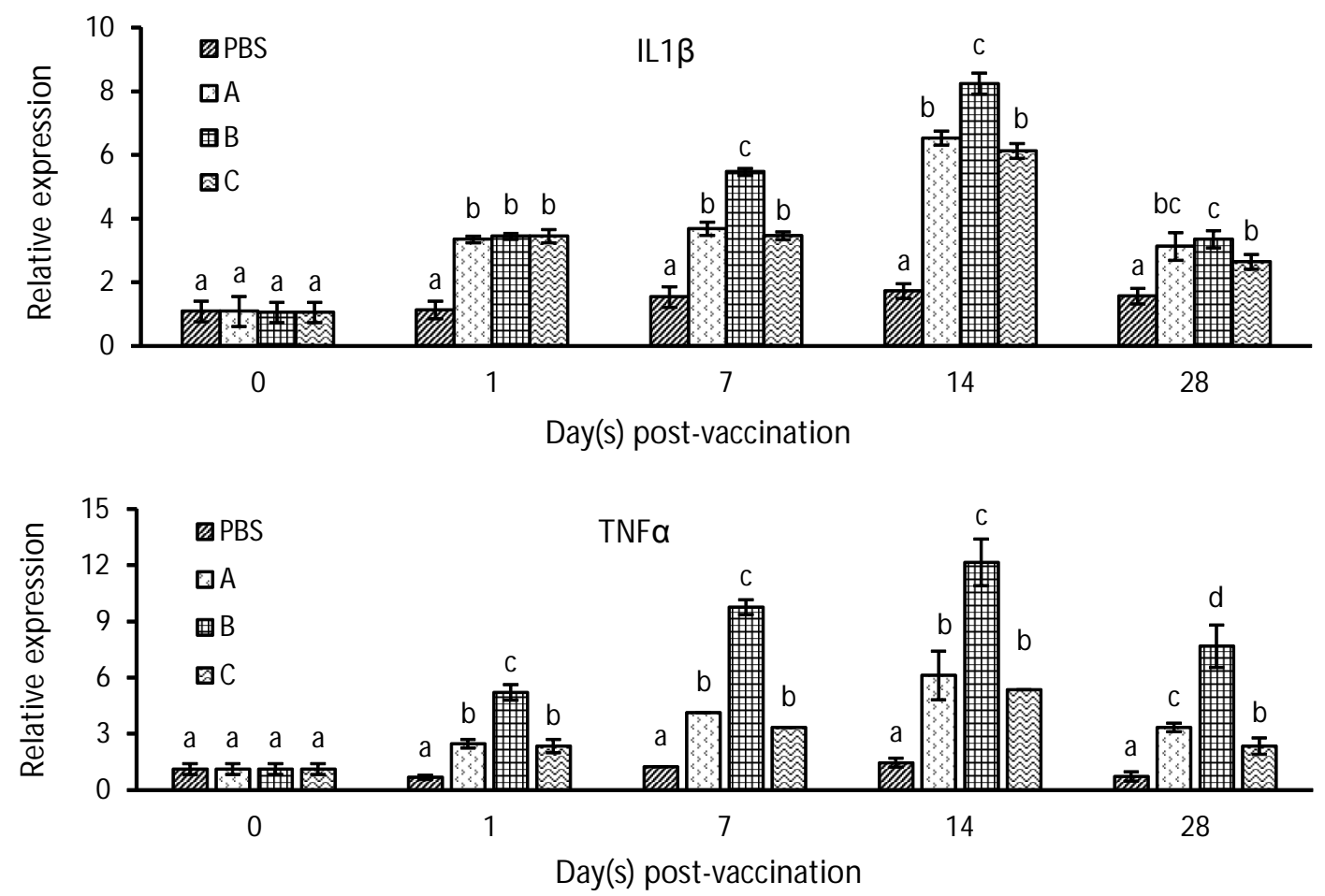

Figure 2. Quantitative relative mRNA expression of ILIb and TNFa of koi fish after vaccination with GP-11 and GP-25 DNA vaccine; (A) $7.5 \mu \mathrm{g} / 100 \mathrm{~g}$ fish GP-11, (B) $12.5 \mu \mathrm{g} /$ $100 \mathrm{~g}$ fish GP-11, (C) $12.5 \mu \mathrm{g} / 100 \mathrm{~g}$ GP-25, (K) PBS control. Data were shown as mean expression $\pm S D(n=3)$. Different letters indicate the significant difference of expression within the treatments at the same time points. 
The expression of both genes has up-regulated since $1 \mathrm{dpv}$ and may be resulted due to a combined effect between the vaccine and injection stress. The cytokines expression was modulated in high-level and peaked at the $14 \mathrm{dpv}$ with the highest expression found at the $12.5 \mu \mathrm{g} / 100 \mathrm{~g}$ of GP-11 vaccination treatment.

DNA vaccines have been used to stimulate protective immunity against many infectious pathogens. Plasmid DNA encoding antigen DNA vaccine is injected into a host. It enters host cells and serves as template for the antigen protein translation (Collins et al., 2018; Zhu et al., 2015). MHC molecules have important roles in viral and bacterial antigen presenta- tion in immune cells such as dendritic cells, B cells, and macrophages (Rakus et al., 2009; Sobhkhez et al., 2018). In this study, The MHC1 and MHC2 expression was up-regulated significantly on the vaccinated fish at $7 \mathrm{dpv}$ (Figure 3). Their expression increased and reached a peak at $28 \mathrm{dpv}$. Consistent with the expression of other immune genes, the $\mathrm{MHCl}$ and $\mathrm{MHC2}$ expressions were also highest in the higher dose of GP-11, compared with the same doses of GP25 vaccine. This is marked by the immunomodulatory effect of the GP11 and GP25 vaccines. This study also showed that the GP11 and GP25 DNA vaccines appeared to be successfully detected as antigens, from their structure or their expressed protein.
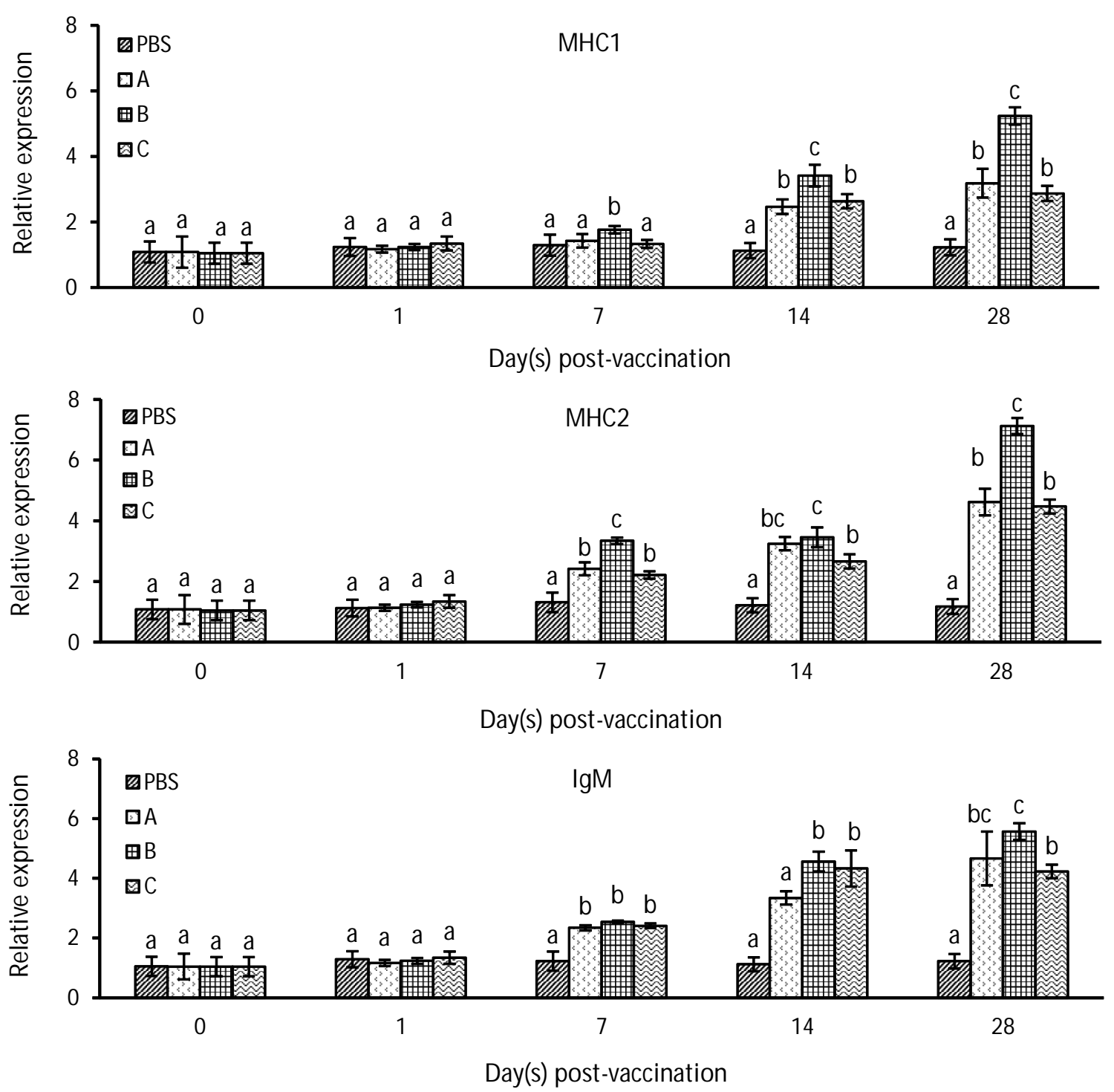

Figure 3. Quantitative relative mRNA expression of $\mathrm{MHC1}, \mathrm{MHC2}$, and $\mathrm{IgM}$ of koi fish after vaccination with GP-11 and GP-25 DNA vaccine; $(\mathrm{A})=7.5 \mu \mathrm{g} / 100 \mathrm{~g}$ fish GP-11, $(\mathrm{B})=12.5$ $\mu \mathrm{g} / 100 \mathrm{~g}$ fish GP-11, $(\mathrm{C})=12.5 \mu \mathrm{g} / 100 \mathrm{~g} \mathrm{GP}-25,(\mathrm{~K})=$ PBS control. Data were shown as mean expression \pm SD $(n=3)$. Different letters indicate the significant difference of expression within the treatments at the same time points. 
The MHC positive cells and IFNã expressions also trigger the specific B- and T-cells responses, leading to antibody production (Schoenborn \& Wilson, 2007; Zhu et al., 2015) as also shown in this study. The mRNA expression of IgM was significantly higher at $7 \mathrm{dpv}$ in all vaccinated fish, indicating that the fish were able to produce the specific antibody for the KHV antigen (Figure 3). The levels of IgM mRNA of the high dose of GP-11 and GP-25 were relatively similar at 7 and $14 \mathrm{dpv}$. But at $28 \mathrm{dpv}$, the expression of IgM was highest in the high dose vaccination using GP-11. The alteration of IgM mRNA may lead to the increasing production of IgM, which was found to be the major targets for the antibody response of carp against KHV (Fuchs et al., 2014).

These immunomodulatory effects of DNA vaccine also have been previously reported in other fish species. The vaccination of Japanese flounder Paralichthys olivaceus with viral hemorrhagic septicemia virus (VSHV) recombinant glycoprotein DNA vaccine resulted in the elevated expression of immune genes (Byon et al., 2006). The IgM and MHC expression were observed to be up-regulated at 1 or $21 \mathrm{dpv}$ in the fish kidney. The vaccination of salmon with the polyprotein salmonidalpha virus (SAV) DNA vaccine resulted in the large increase of proinflammatory cytokines IL1 $\beta$ and TNF $\alpha$, IFNs genes, Mx gene, and also MHC and IgM gene after one and two weeks post-injection (Sobhkhez et al,, 2017; Sobhkhez et al., 2018). The protective immunity also has shown by the vp7 gene of grass carp reovirus DNA vaccine injection in grass carp (Zhu et al., 2015). The grass carp IL1 $\beta$, TNF $\alpha$, IFN $\gamma$, complement-3, MHC1, MHC2, and IgM gene transcript was significantly modulated 28 days after vaccination. The similar findings in our current study could further explain our previous studies'results related to the protective effects of both vaccines in koi after KHV infection (Aonullah et al., 2016; Chairunnisa et al., 2016; Nuryati et al., 2010; 2015). These differences in the immune gene expressions may help to identify the important components of the koi immune system for conferring an immune response against KHV disease.

\section{CONCLUSIONS}

In conclusion, the GP-11 and GP-25, encoding the ORF81 and ORF25 of the KHV glycoprotein gene, provided the immune-modulatory effects on the koi fish immune response after vaccination. The higher dose vaccination using the GP-11 vaccine showed a higher immune response than its lower dose. Furthermore, the GP-25 vaccination resulting in the lower immune responses than the GP-11 vaccine using the same dose of vaccination, but relatively the same to that of the half-dose of GP-11 vaccine.

\section{ACKNOWLEDGMENTS}

This research was partially supported by PSU Research Grant No: 1703/IT3.11/PN/2018 from the Ministry of Research and Higher Education, Indonesia. The authors thank Dendi Hidayatullah and Lina Mulyani for their help in the laboratory analysis.

\section{REFERENCES}

Aoki, T., Hirono, I., Kurokawa, K., Fukuda, H., Nahary, R., Eldar, A., Davidson, A.J., Waltzek, T.B., Bercovier, H., \& Hedrick, R.P. (2007). Genome sequences of three koi herpesvirus isolates representing the expanding distribution of an emerging disease threatening koi and common carp worldwide. Journal of Virology, 81(10), 5058-5065. https://doi.org/10.1128//VI.00146-07.

Aonullah, A.A., Nuryati, S., \& Murtini, S. (2016). Efficacy of koi herpesvirus DNA vaccine administration by immersion method on Cyprinus carpio field scale culture. Aquaculture Research, 48, 2655-2662. https://doi.org/10.1111/are.13097.

Bedekar, M.K., Soman, P., Kole, S., Depika, A., Tripathi, G., Makesh, M., \& Rajendran, K.V. (2018). Evaluation of interferon gamma (IFN- $\gamma$ ) of Labeo rohita as an immunomodulator: In vitro expression model. Aquaculture International, 26, 1401-1413. https://doi.org/10.1007/s10499-018-0292-9.

Bird, S., Zou, J., Wang, T., Munday, B., Cunningham, C., \& Secombes, C.J. (2002). Evolution of interleukin-1â. Cytokine and Growth Factor Reviews, 13(6), 483-502. https://doi.org/10.1016/S13596101(02)00028-X.

Byon, J.Y., Ohira, T., Hirono, I., \& Aoki, T. (2006). Comparative immune responses in Japanese flounder, Paralichthys olivaceus after vaccination with viral hemorrhagic septicemia virus (VHSV) recombinant glycoprotein and DNA vaccine using a microarray analysis. Vaccin e, 25(7), 921-930. https://doi.org/10.1016/j.vaccine.2005.08.087.

Chairunnisa, S.A., Nuryati, S., Alimuddin, Murtini, S., Santika, A., \& Yanti, D.H. (2016). Efficacy of Gp11 khv DNA vaccine in Cyprinus carpio haematopterus. Indonesian Aquaculture Journal, 11(1), 31-39.

Collins, C., Lorenzen, N., \& Collet, B. (2018). DNA vaccination for finfish aquaculture. Fish $\&$ Shellfish Immunology, 85, 106-125. https://doi.org/10.1016/ j.fsi.2018.07.012. 
Cui, L.C., Guan, X.T., Liu, Z.M., Tian, C.Y., \& Xu, Y.G. (2015). Recombinant lactobacillus expressing $G$ protein of spring viremia of carp virus (SVCV) combined with ORF81 protein of koi herpesvirus $(\mathrm{KHV})$ : A promising way to induce protective immunity against SVCV and KHV infection in cyprinid fish via oral vaccination. Vaccine, 33(27), 30923099. https://doi.org/10.1016/j.vaccine.2015. 05.002 .

Eide, K.E., Miller-morgan, T., Heidel, J.R., Kent, M.L., Bildfell, R.J., Lapatra, S., Watson, G., \& Jin, L. (2011). Investigation of koi herpesvirus latency in koi. Journal of Virology, 85(10), 4954-4962. https:/ /doi.org/10.1128/JVI.01384-10.

Embregts, C.W.E., Tadmor-Levi, R., Veselý, T., Pokorová, D., David, L., Wiegertjes, G.F., \& Forlenza, M. (2018). Intra-muscular and oral vaccination using a koi herpesvirus ORF25 DNA vaccine does not confer protection in common carp (Cyprinus carpio L.). Fish and Shellfish Immunology, 85, 90-98. https://doi.org/10.1016/j.fsi.2018. 03.037 .

Fuchs, W., Granzow, H., Dauber, M., Fichtner, D., \& Mettenleiter, T.C. (2014). Identification of structural proteins of koi herpesvirus. Archives of Virology, 159, 3257-3268. https://doi.org/10.1007/ s00705-014-2190-4.

Kim, C.H., Johnson, M.C., Drennan, J.D., Simon, B.E., Thomann, E., \& Leong, J.C. (2000). DNA vaccines encoding viral glycoproteins induce nonspecific immunity and $m x$ protein synthesis in fish. J. Virol., 74(15), 7048-54. doi: 10.1128/jvi.74.15.70487054.2000 .

Lazarte, J.M.S., Kim, Y.R., Lee, J.S., Im, S.P., Kim, S.W., Jung, J.W., Kim, J., Lee, W.J., \& Jung, T.S. (2017). Enhancement of glycoprotein-based DNA vaccine for viral hemorrhagic septicemia virus (VHSV) via addition of the molecular adjuvant. Fish and Shellfish Immunol., 62, 356-365. doi: 10.1016/ j.fsi.2017.01.031.

Leong, J.C., Trobridge, G.D., \& Kim, C.H.Y. (1998). Interferon-inducible $\mathrm{Mx}$ proteins in fish. Immunological Review, 166, 349-364.

Livak, K.J. \& Schmittgen, T.D. (2001). Analysis of relative gene expression data using real-time quantitative PCR and the 2-ÄÄCT method. M ethods, 25(4), 402-408. https://doi.org/10.1006/meth.2001.1262.

Mccoll, K.A., Sunarto, A., \& Neave, M.J. (2018). Biocontrol of carp/: More than just a herpesvi- rus. Frontiers in Microbiology, 9(September), 1-5. https://doi.org/10.3389/fmicb.2018.02288.

Nuryati, S., Alimuddin, A., Sukenda, S., Soejoedono, R.D., Santika, A., Pasaribu, F.H., \& Sumantadinata, K. (2010). Construction of a DNA vaccine using glycoprotein gene and its expression towards increasing survival rate of KHV-Infected common carp (Cyprinus carpio). Jurnal Natur Indonesia, 13(65), 47-52.

Nuryati, S., Khodijah, S., Alimuddin, A., \& Setiawati, M. (2015). Effectiveness of DNA vaccine in feed to koi herpesvirus-infected common carp. Jurnal Kedokteran Hewan, 9(1), 33-37. https://doi.org/ 10.21157/j.ked.hewan.v9i1.2784.

OIE. (2019). Infection with koi herpesvirus. In Manual of Diagnostic Tests for Aquatic Animals, p. 1-18.

Rakus, K., Wiegertjes, G.F., Adamek, M., Siwicki, A.K., Lepa, A., \& Irnazarow, I. (2009). Resistance of common carp (Cyprinus carpio L.) to Cyprinid herpesvirus-3 is influenced by major histocompatibility (MH) class II B gene polymorphism. Fish and Shellfish Immunology, 26(5), 737-743. https://doi.org/ 10.1016/j.fsi.2009.03.001.

Schoenborn, J.R. \& Wilson, C.B. (2007). Regulation of interferon- $g$ during innate and adaptive immune responses. Advances in Immunology, 96, 41-101. https://doi.org/10.1016/S00652776(07)96002-2.

Sobhkhez, M., Krasnov, A., Chang, C.J., \& Robertsen, B. (2017). Transcriptome analysis of plasmid-induced genes sheds light on the role of type I IFN as adjuvant in DNA vaccine against infectious salmon anemia virus. PLOS ONE, November, p. 1-20.

Sobhkhez, M., Krasnov, A., \& Id, R. (2018). Transcriptome analyses of Atlantic salmon muscle genes induced by a DNA vaccine against salmonid alphavirus, the causative agent of salmon pancreas disease (PD). PLOS ONE, October, p. 1-16.

Zhu, B., Liu, G.L., Gong, Y.X., Ling, F., \& Wang, G.X. (2015). Protective immunity of grass carp immunized with DNA vaccine encoding the vp7 gene of grass carp reovirus using carbon nanotubes as a carrier molecule. Fish and Shellfish Immunology, 42(2), 325-334. https://doi.org/10.1016/ j.fsi.2014.11.026.

Zou, J. \& Secombes, C. (2016). The function of fish cytokines. Biology, 5(2), 23. https://doi.org/10.3390/ biology 5020023. 


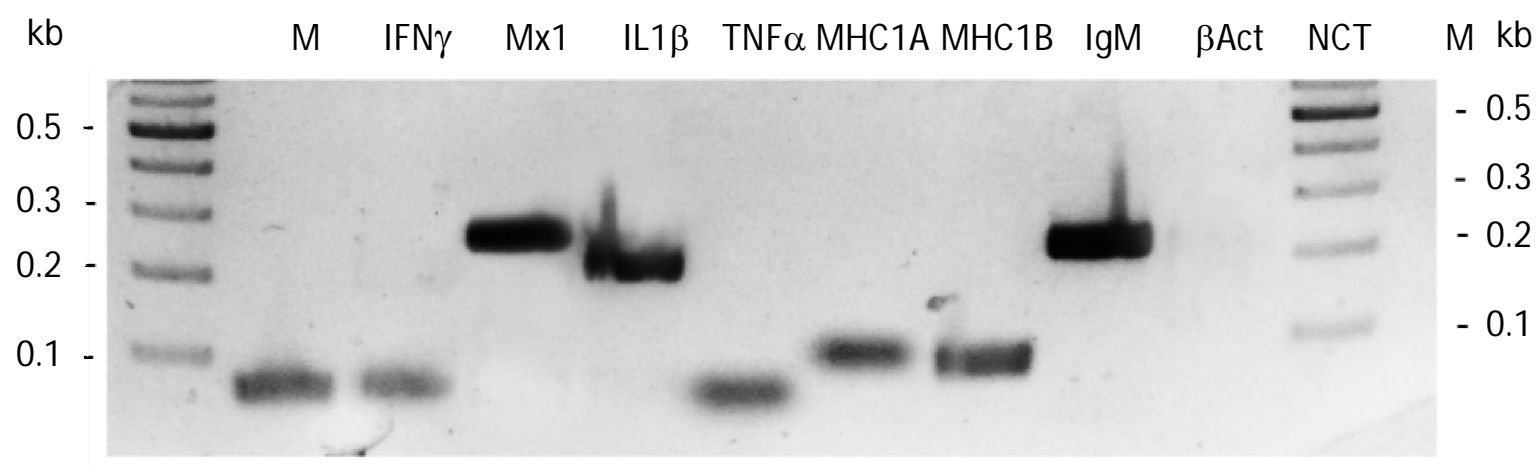

Supplementary Figure. Agarose gel electrophoresis of various immune-related genes expression of koi fish. $\mathrm{kb}=$ kilobasepairs, $M=100$ bp DNA markers. 